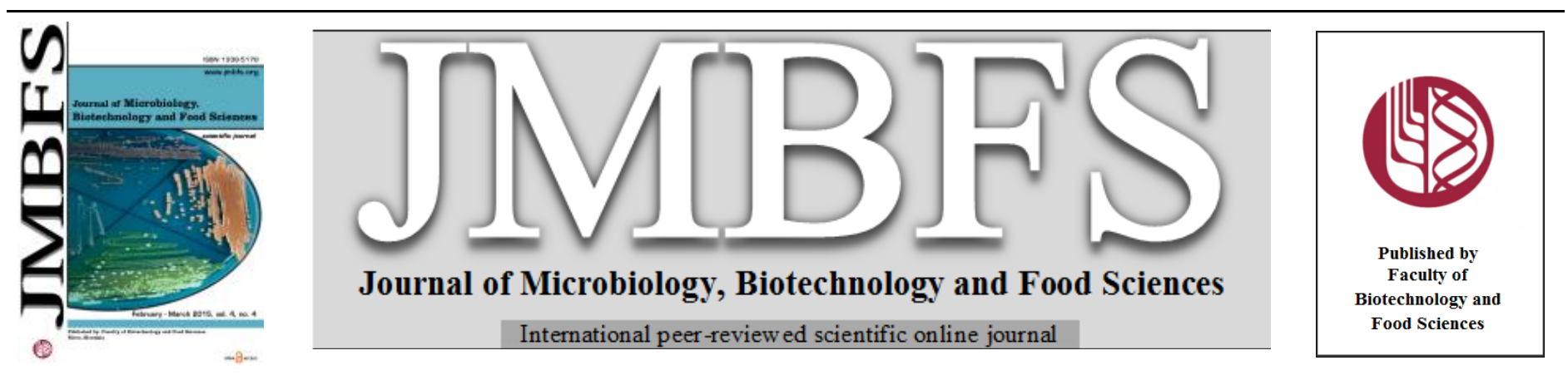

\title{
QUALITY OF YOGHURTS FROM GOAT'S MILK ENRICHED WITH MAGNESIUM CHLORIDE
}

\section{Agata Znamirowska*, Dorota Kalicka, Małgorzata Pawlos, Katarzyna Szajnar}

Address(es):

University of Rzeszow, Faculty of Biology and Agriculture, Department of Dairy Technology, Ćwiklinskiej 2D St., 35-601 Rzeszow, +48177854903.

*Corresponding author: aznam@univ.rzeszow.pl

doi: 10.15414/jmbfs.2015.4.4.369-372

\section{ARTICLE INFO}

Received 5. 12. 2014

Revised 14. 12. 2014

Accepted 7. 1. 2015

Published 1. 2. 2015

Regular article

open $O$ access

\begin{abstract}
Goat's milk can be enriched with magnesium in the form of chloride before pasteurization with a save dose, i.e. $20 \mathrm{mg}$ of magnesium for $100 \mathrm{~g}$ of milk. Higher doses of magnesium can lead to coagulation of proteins since together with the increase of the dose of fortification there increases general acidity while $\mathrm{pH}$ of milk decreases. Together with the increase of the dose of fortification of yoghurts with magnesium there was shown an essential proportional increase of acidity and hardness of curds persisting for 21 days of storage. Enriching goat's milk yoghurts with magnesium decreased the intensity of „goat” smell and aftertaste and did not cause a change in colour. The most favourable solution is the production of goat's milk yoghurts enriched with $10-20 \mathrm{mg}$ of magnesium in the form of magnesium chloride. Such doses of enrichment caused successive lowering of perceptibility of „goat” aftertaste and smell together with extension of storage time.
\end{abstract}

Keywords: Magnesium, fortification, yoghurt, goat's milk

\section{INTRODUCTION}

Man should take from 300 to $350 \mathrm{mg}$ of magnesium with food every day. In a typical diet, together with food there comes to the organism daily only $2 / 3$ of the needed dose and its deficiency is $1 / 3$ on average, i.e. about $100 \mathrm{mg}$. As Wojtaszek (2004) says, when supplementing magnesium, calcium should be given at the same time. In milk and fermented goat's milk beverages there is on average $10-17 \mathrm{mg}$ of magnesium and $110-120 \mathrm{mg}$ of calcium in 100 grams. Thus, goat's milk is classified to products of low content of magnesium but high content of calcium. Dieticians suggest that a well balanced diet should provide two parts of calcium and phosphorus for one part of magnesium. Balancing the content of magnesium in relation to calcium in milk products can produce additional nutritional benefits for consumers. The average use of magnesium by human organism is from 40 to $50 \%$, and its absorption increases in the presence of protein and lactose (Ziarno, 2004; Ziarno, 2008; Ziarno et al., 2009). Due to the presence of these two components in milk - both milk as well as fermented milk beverages can be a good carrier of magnesium.

Fermented beverages based on goat's milk differ in many aspects from their homologues from cow's milk. In consumers' opinion, goat's milk and products are regarded as products of healthful properties. The use of goat's milk for production of fermented beverages fortified with magnesium favours retaining or even increasing of its nutritional, dietetic and also therapeutic value (Mituniewicz-Małek et al., 2009; Navarro-Alarcón et al., 2011; Ribeiroa and Riberioa, 2010).

The aim of the paper was to determine the influence of applied dose of magnesium chloride in goat's milk before its pasteurization on physiochemical and organoleptic properties and texture of yoghurts during 21-day period of storage.

\section{MATERIAL AND METHODS}

\section{Materials}

The research material was cumulative goat's milk collected three times in the middle of lactation (June-September). For milk and yoghurts enrichment magnesium chloride $\left(\mathrm{MgCl}_{2} \times 6 \mathrm{H}_{2} \mathrm{O}\right.$, pure for analysis, $\left.\mathrm{POCH}\right)$ was used.

\section{Milk analysis}

In raw milk there were determined physiochemical and microbiological parameters (Tab 1) and then fat was spun and the content of dry matter was normalized. The general number of micro-organisms and the number of somatic cells were determined in IBC M/SCC (Bentley) semi-automatic counter, and the chemical composition was determined in Bentley B-150 milk composition analyser. The chemical composition of milk used for production of yoghurts is presented in table 2 .

Table 1 Quality of raw goat's milk

\begin{tabular}{ll}
\hline \hline Properties & Average \pm standard deviation \\
\hline \hline General number of micro-organisms & $515000 \pm 12200$ \\
$(\mathrm{CFU} / \mathrm{ml})$ & $865000 \pm 32660$ \\
Number of somatic cells $(1 \mathrm{ml})$ & $6.57 \pm 0.37$ \\
$\mathrm{pH}$ & $6.20 \pm 1.20$ \\
General acidity $\left({ }^{\circ} \mathrm{SH}\right)$ & $-0.5685 \pm 0.002$ \\
Freezing point $\left({ }^{\circ} \mathrm{C}\right)$ & $2.69 \pm 0.22$ \\
Protein $(\%)$ & $2.98 \pm 0.53$ \\
Fat $(\%)$ & $4.02 \pm 0.32$ \\
Lactose $(\%)$ & $10.78 \pm 0.35$ \\
Dry matter $(\%)$ & \\
\hline \hline
\end{tabular}

Table 2 Chemical composition of normalized milk for production of yoghurts

\begin{tabular}{ll}
\hline \hline Properties & Average \pm standard deviation \\
\hline \hline Protein $(\%)$ & $3.84 \pm 0.11$ \\
Fat $(\%)$ & $2.02 \pm 0.01$ \\
Lactose $(\%)$ & $6.40 \pm 0.22$ \\
Dry matter $(\%)$ & $13.75 \pm 0.10$ \\
\hline \hline
\end{tabular}

\section{Heat stability of milk enriched in magnesium chloride}

The experiment was conducted in two stages. The scope of tests of the first stage included determining the quantity of addition of magnesium chloride $\left(\mathrm{MgCl}_{2} \times 6 \mathrm{H}_{2} \mathrm{O}\right.$, pure for analysis, $\left.\mathrm{POCH}\right)$ not causing thermal denaturation of proteins of milk during its pasteurization in temperature of $72^{\circ} \mathrm{C}$ for 15 seconds. The doses of magnesium presented in tables were calculated basing on molecular weight of hexahydrous magnesium chloride. The experiment started with the dose of $0.1 \mathrm{mg}$ of magnesium for $100 \mathrm{~g}$ of milk and continued until occurrence of denaturation during pasteurization. There was also made a test sample without 
addition of magnesium. After cooling milk samples there were determined $\mathrm{pH}$ and general acidity.

\section{Preparation of yoghurts}

The scope of the second stage of tests included production of yoghurt with the thermostatic method of various levels of enrichment with magnesium $(0 \mathrm{mg}, 5$ $\mathrm{mg}, 10 \mathrm{mg}, 15 \mathrm{mg}$ and $20 \mathrm{mg}$ ) with the use of the vaccine FD-DVS YC-X16 (Chr.Hansen). Fermentation was conducted for 4.5 hours in disposable containers with lids $(100 \mathrm{ml})$ in temperature of $43^{\circ} \mathrm{C}$.

\section{Yoghurts analysis}

The assessment of the influence of addition of magnesium chloride on acidity, texture and sensory characteristics (1-9 points) was conducted at four fixed dates, i.e. after 1 day, 7 days, 14 days and 21 days of storage. Determining potential acidity was performed by titration of $0.25 \mathrm{~N}$ samples with standard solution of sodium hydroxide in presence of phenolphthalein as an indicator. Determining active acidity $(\mathrm{pH})$ was performed with the electrometric method by measurement of activity of hydrogen ions with the use of $\mathrm{pH} /$ conductivity meter CPC - 505 (Elmetron) equipped with the combination electrode OSH $12-00$ The texture was determined with the analyser Brookfield CT3 equipped with Brookfield Texture Pro CT software. For determination there was selected the TPA test with the following settings: sample - cylinder $66.00 \mathrm{~mm} \times 33.86 \mathrm{~mm}$, force $0.1 \mathrm{~N}$, head speed $1 \mathrm{~mm} / \mathrm{s}$, table TA-BT-KIT, probe TA3/100.

\section{Statistical analysis}

The obtained results were worked out statistically in the software Statistica v.10 with the use of one-way analysis of variance, and significance of differences between the averages was estimated with Tukey's test.

\section{RESULTS AND DISCUSSION}

This paper deals with production of yoghurt enriched with magnesium in the form of chloride put in goat's milk before pasteurization. Putting hexahydrous chloride in production at this stage reduces the risk of post-pasteurization microbiological contamination of processed milk, and hence the finished product. Such a technological solution at production requires determination of the influence of added chloride on thermal stability of proteins of goat's milk and determination of maximum save level of fortification dose.

\section{Effect of pasteurization on enriched goat's milk}

The conducted tests proved that putting in goat's milk of higher and higher doses of water-soluble salt, i.e. hexahydrous magnesium chloride, caused a reduction of $\mathrm{pH}$ and an increase of general acidity of milk (Fig 1).

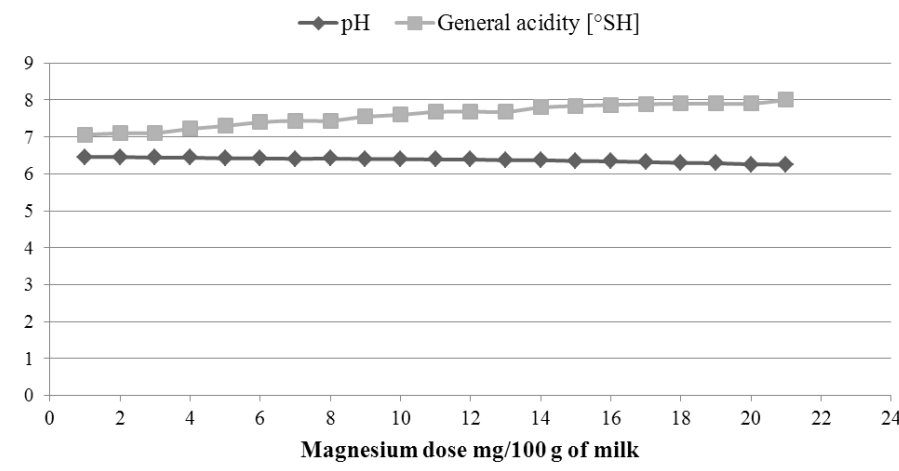

Figure 1 Influence of applied dose of magnesium in the form of hexahydrous chloride on $\mathrm{pH}$ and general acidity of milk after pasteurization

It was also observed that depending on the date of tests there changed the dose of chloride which caused precipitation of proteins after pasteurization. The doses of fortification with magnesium causing precipitation of curd were from $22 \mathrm{mg}$ to $25 \mathrm{mg}$ of magnesium for $100 \mathrm{~g}$ of milk. Taking into account this variability, for goat's milk fortification on industrial scale a lower dose should be determined, hence a dose safe for the whole period of lactation. Using hexahydrous magnesium chloride for enrichment, such an amount can be assumed to be $20 \mathrm{mg}$ of magnesium for $100 \mathrm{~g}$ of milk

\section{Effect of fortification on acidity of yoghurts}

The test yoghurts, without addition of magnesium chloride, were characterized during the whole period of storage by higher values of $\mathrm{pH}(\mathrm{p}<0.01)$ and lower potential acidity $(\mathrm{p}<0.01)$ in comparison to fortified samples (Tab 3 and 4$)$.

The detailed analysis of results of authors' tests shows that the greatest influence of the dose of applied magnesium on active and general acidity of yoghurts is observed on the first day of storage. However, during successive weeks of cold storage of fortified yoghurts these differences faded away, especially within the values of active acidity.

Table 3 The influence of dose of enrichment with magnesium on active acidity of goat's milk yoghurts during storage

\begin{tabular}{lccccc}
\hline \hline $\begin{array}{l}\text { Characteristic } \\
\text { fixed } \begin{array}{c}\text { date } \\
\text { determination }\end{array}\end{array}$ & \begin{tabular}{c} 
of \\
\cline { 2 - 5 }
\end{tabular} & 0 & 5 & 10 & 15 \\
\hline \hline $\mathrm{pH}$ - 1 day & $4.32^{\mathrm{a}} \pm 0.01$ & $4.28^{\mathrm{b}} \pm 0.01$ & $4.28^{\mathrm{b}} \pm 0.01$ & $4.27^{\mathrm{b}} \pm 0.02$ \\
$\mathrm{pH}-7$ days & $4.22^{\mathrm{a}} \pm 0.03$ & $4.18^{\mathrm{b}} \pm 0.01$ & $4.18^{\mathrm{b}} \pm 0.01$ & $4.18^{\mathrm{b}} \pm 0.01$ \\
$\mathrm{pH}-14$ days & $4.16^{\mathrm{a}} \pm 0.02$ & $4.10^{\mathrm{ab}} \pm 0.05$ & $4.09^{\mathrm{b}} \pm 0.02$ & $4.24^{\mathrm{c}} \pm 0.02$ \\
$\mathrm{pH}$ - 21 days & $4.05^{\mathrm{a}} \pm 0.02$ & $4.00^{\mathrm{b}} \pm 0.01$ & $3.99^{\mathrm{b}} \pm 0.01$ & $4.17^{\mathrm{b}} \pm 0.01$ \\
\hline
\end{tabular}

Legend: ${ }^{\mathrm{a}-\mathrm{c}}-$ statistically significant differences $(\mathrm{p}<0.05)$ analysed in row

Table 4 The influence of dose of enrichment with magnesium on general acidity of goat's milk yoghurts during storage

\begin{tabular}{lcccc}
\hline \hline \multirow{2}{*}{$\begin{array}{l}\text { Characteristic }- \text { fixed } \\
\text { date of determination }\end{array}$} & \multicolumn{4}{c}{ Dose of enrichment with magnesium (mg of magnesium for 100 g of milk) } \\
\cline { 2 - 5 } & 0 & 5 & 10 & 15 \\
\hline \hline General acidity - 1 day & $40.26^{\mathrm{a}} \pm 0.70$ & $41.82^{\mathrm{b}} \pm 0.60$ & $42.74^{\mathrm{bc}} \pm 0.73$ & $43.36^{\mathrm{c}} \pm 0.61$ \\
General acidity - 7 days & $44.42^{\mathrm{a}} \pm 0.40$ & $46.00^{\mathrm{b}} \pm 0.36$ & $45.84^{\mathrm{b}} \pm 0.95$ & $46.16^{\mathrm{b}} \pm 0.29$ \\
General acidity - 14 days & $42.82^{\mathrm{a}} \pm 0.47$ & $44.16^{\mathrm{b}} \pm 0.53$ & $44.70^{\mathrm{bc}} \pm 0.35$ & $44.72^{\mathrm{bc}} \pm 0.66$ \\
General acidity - 21 days & $43.67^{\mathrm{a}} \pm 0.34$ & $44.61^{\mathrm{b}} \pm 0.15$ & $44.80^{\mathrm{c}} \pm 0.38$ & $44.87^{\mathrm{c}} \pm 0.68$ \\
\hline Legend: ${ }^{\mathrm{a}-\mathrm{c}}-$ statistically significant differences $(\mathrm{p}<0.05)$ analysed in row & $45.20^{\mathrm{c}} \pm 0.56$ & 4.69 \\
\hline
\end{tabular}

\section{Effect of fortification on sensory and textural properties of yoghurts}

Pozakova et al. (1999) compared the results of sensory assessment of yoghurts from goat's, cow's and sheep's milk. Goat's milk yoghurts got the lowest number of points and at the same time too loose consistency of curd had the greatest impact on lowering of the general sensory assessment. In the conducted experiment the 5-7 person team with proved sensory sensitivity assessed in the scale of 1-9 points (1- little characteristic, 9- very characteristic) the impact of the applied dose of enrichment with magnesium on consistency of yoghurts during storage. The results presented in table 5 and the conducted statistical analysis showed significant differences between consistency of enriched yoghurts and non-fortified ones for the whole period of storage. The consistency of yoghurts not enriched with magnesium was too loose, thus these yoghurts got definitely lower marks in comparison to yoghurts fortified with magnesium. 
Table 5 The influence of dose of enrichment with magnesium on consistency of goat's milk yoghurts during storage (1-9 points)

\begin{tabular}{|c|c|c|c|c|c|}
\hline \multirow{2}{*}{$\begin{array}{l}\text { Characteristic - fixed date } \\
\text { of determination }\end{array}$} & \multicolumn{5}{|c|}{ Dose of enrichment with magnesium (mg of magnesium for $100 \mathrm{~g}$ of milk) } \\
\hline & 0 & 5 & 10 & 15 & 20 \\
\hline Consistency - 1 day & $7.00^{\mathrm{a}} \pm 0.00$ & $8.40^{\mathrm{b}} \pm 0.89$ & $8.60^{\mathrm{b}} \pm 0.54$ & $8.80^{\mathrm{b}} \pm 0.44$ & $9.00^{b} \pm 0.00$ \\
\hline Consistency -7 days & $7.00^{\mathrm{a}} \pm 0.70$ & $7.40^{\mathrm{b}} \pm 0.54$ & $7.60^{b} \pm 0.54$ & $8.60^{c} \pm 0.54$ & $9.00^{c} \pm 0.00$ \\
\hline Consistency -14 days & $6.80^{\mathrm{a}} \pm 0.83$ & $7.80^{\mathrm{b}} \pm 0.83$ & $8.00^{b} \pm 0.70$ & $8.80^{c} \pm 0.44$ & $8.75^{\mathrm{c}} \pm 0.50$ \\
\hline Consistency -21 days & $8.40^{\mathrm{a}} \pm 0.24$ & $8.60^{\mathrm{b}} \pm 0.54$ & $8.60^{b} \pm 0.54$ & $8.80^{\mathrm{c}} \pm 0.24$ & $8.75^{\mathrm{c}} \pm 0.24$ \\
\hline
\end{tabular}

Enriching yoghurt with the dose of $5 \mathrm{mg}$ of magnesium (for $100 \mathrm{mg}$ of milk for production) already caused a significant improvement of consistency, and the higher doses still definitely increased hardness of curd.

According to Tamime et al. (1984, 1998), textural properties and structure of yoghurt curd are determined mainly by the content of dry matter, especially protein. To exclude the influence of this factor, goat's milk applied in the experiment was normalized to the content of dry matter $13.75 \%$ and protein $3.84 \%$ in all repetitions.

Substances being the carrier of magnesium should not have an adverse impact on a change in colour, taste and smell of the product, shorten the shelf life or cause a change in the product during transport and storage (Ziarno et al., 2009). The conducted assessment of colour of yoghurts showed no influence of addition of magnesium chloride on the colour of yoghurts during the whole period of storage. However, the sensory panel found differences in taste and smell of yoghurts enriched with magnesium, especially in comparison to non-fortified yoghurts. In yoghurts fortified with magnesium assessed after one day of storage there was found more intense milky-creamy taste (Tab 6), however the results of assessment on later dates do not significantly diversify yoghurts enriched with magnesium in comparison to fortified ones with regard to intensity of milkycreamy taste. In turn, the quantity of magnesium significantly influenced sourness of the yoghurt's taste, especially after three weeks of storage (Tab 7) There was found after this time evidently lower sourness of yoghurts enriched with doses of $10 \mathrm{mg}$ of magnesium and higher.

\begin{tabular}{lcccc} 
Table 6 The influence of doses of enrichment with magnesium on perceptibility of milky-creamy taste of goat's milk yoghurts during storage (1-9 \\
\hline \hline \multirow{2}{*}{$\begin{array}{l}\text { Characteristic }- \text { fixed date of } \\
\text { determination }\end{array}$} & \multicolumn{2}{c}{ Dose of enrichment with magnesium (mg of magnesium for 100 g of milk) } \\
\cline { 2 - 5 } & 0 & 5 & 10 & 15 \\
\hline \hline Milky-creamy taste -1 day & $3.80^{\mathrm{a}} \pm 1.64$ & $5.20^{\mathrm{a}} \pm 2.05$ & $5.20^{\mathrm{a}} \pm 1.30$ & $5.60^{\mathrm{a}} \pm 1.67$ \\
Milky-creamy taste -7 days & $4.40^{\mathrm{a}} \pm 1.67$ & $5.00^{\mathrm{a}} \pm 1.87$ & $4.80^{\mathrm{a}} \pm 1.64$ & $5.20^{\mathrm{a}} \pm 1.09$ \\
Milky-creamy taste -14 days & $3.60^{\mathrm{a}} \pm 1.341$ & $4.00^{\mathrm{a}} \pm 2.00$ & $4.00^{\mathrm{a}} \pm 1.00$ & $5.25^{\mathrm{b}} \pm 0.95$ \\
Milky-creamy taste -21 days & $3.60^{\mathrm{a}} \pm 0.89$ & $4.00^{\mathrm{a}} \pm 1.00$ & $4.40^{\mathrm{a}} \pm 0.55$ & $4.75^{\mathrm{a}} \pm 0.95$ \\
\hline
\end{tabular}

Legend: ${ }^{a-c}-$ statistically significant differences $(\mathrm{p}<0.05)$ analysed in row

Table 7 The influence of dose of enrichment with magnesium on perceptibility of sour taste of goat's milk yoghurts (1-9 points) during storage

\begin{tabular}{lcccc}
\hline \multirow{2}{*}{$\begin{array}{l}\text { Characteristic }- \text { fixed date of } \\
\text { determination }\end{array}$} & \multicolumn{1}{c}{ Dose of enrichment with magnesium (mg of magnesium for 100 g of milk) } \\
\cline { 2 - 5 } & 0 & 5 & 10 & 15 \\
\hline Sour taste -1 day & $5.60^{\mathrm{a}} \pm 1.14$ & $6.00^{\mathrm{a}} \pm 1.22$ & $6.20^{\mathrm{a}} \pm 1.30$ & $6.80^{\mathrm{b}} \pm 1.30$ \\
Sour taste -7 days & $6.60^{\mathrm{a}} \pm 0.83$ & $6.60^{\mathrm{a}} \pm 1.14$ & $5.80^{\mathrm{a}} \pm 1.14$ & $5.80^{\mathrm{a}} \pm 0.83$ \\
Sour taste -14 days & $5.80^{\mathrm{a}} \pm 0.54$ & $6.00^{\mathrm{a}} \pm 1.00$ & $5.60^{\mathrm{a}} \pm 0.54$ & $5.60^{\mathrm{a}} \pm 0.54$ \\
Sour taste -21 days & $5.40^{\mathrm{a}} \pm 1.14$ & $5.40^{\mathrm{a}} \pm 0.54$ & $5.00^{\mathrm{b}} \pm 0.71$ & $5.00^{\mathrm{a}} \pm 1.25$ \\
\hline Legend: ${ }^{\mathrm{a}-\mathrm{c}}-$ statistically significant differences $(\mathrm{p}<0.05)$ analysed in row & & & $4.40^{\mathrm{c}} \pm 1.14$ \\
\hline
\end{tabular}

Moreover, already on the first date of determination it was observed that together with the increase of fortification dose there decreases perceptibility of the characteristic goat taste and smell (Tab 8 and 9). While in yoghurts not enriched with magnesium the intensity of goat taste and smell increases together with extension of storage time, in fortified yoghurts these characteristics are evidently less perceptible. The carried-out experiment explicitly shows that the quantity of enrichment with hexahydrous magnesium chloride of goat's milk intended for production of yoghurt decides on goat taste and smell intensity in the finished product. A specific taste and smell of goat's milk products sharpening together with storage time are often unacceptable for the Polish consumers and prevents them from purchase. The use of enrichment with magnesium and production of goat yoghurt which, as a result of fortification, does not take sour and goat taste together with extension of storage time and has a nice smell, is a good prospect for promotion of goat's milk functional beverages. The most favourable solution for the industrial technology is production of yoghurt enriched with a dose of at least $10 \mathrm{mg}$ of magnesium for $100 \mathrm{~g}$ of milk. It is highly probable that it is this kind of yoghurt that will be most eagerly purchased by consumers.

Table 8 The influence of dose of enrichment with magnesium on perceptibility of goat taste of goat's milk yoghurts during storage (1-9 points)

\begin{tabular}{lcccc}
\hline \hline \multirow{2}{*}{$\begin{array}{l}\text { Characteristic }- \text { fixed date of } \\
\text { determination }\end{array}$} & \multicolumn{2}{c}{ Dose of enrichment with magnesium (mg of magnesium for 100 g of milk) } \\
\cline { 2 - 5 } & 0 & 5 & 10 & 15 \\
\hline \hline "Goat" taste -1 day & $4.20^{\mathrm{a}} \pm 1.48$ & $3.00^{\mathrm{a}} \pm 0.58$ & $2.00^{\mathrm{b}} \pm 0.41$ & $1.80^{\mathrm{b}} \pm 0.23$ \\
"Goat" taste -7 days & $4.20^{\mathrm{a}} \pm 0.83$ & $2.80^{\mathrm{b}} \pm 0.83$ & $2.20^{\mathrm{b}} \pm 0.44$ & $1.40^{\mathrm{c}} \pm 0.54$ \\
"Goat" taste -14 days & $4.60^{\mathrm{a}} \pm 0.54$ & $2.20^{\mathrm{b}} \pm 0.44$ & $1.60^{\mathrm{b}} \pm 0.54$ & $1.50^{\mathrm{b}} \pm 0.37$ \\
"Goat" taste -21 days & $5.60^{\mathrm{a}} \pm 0.54$ & $1.80^{\mathrm{b}} \pm 0.44$ & $1.60^{\mathrm{b}} \pm 0.54$ & $1.25^{\mathrm{c}} \pm 0.50$ \\
\hline Legend: ${ }^{\mathrm{a}-\mathrm{c}}-$ statistically significant differences $(\mathrm{p}<0.05)$ analysed in row & & $1.50^{\mathrm{b}} \pm 0.57$ \\
\end{tabular}

Legend: ${ }^{\mathrm{a}-\mathrm{c}}-$ statistically significant differences $(\mathrm{p}<0.05)$ analysed in row

Table 9 The influence of dose of enrichment with magnesium on perceptibility of goat smell of goat's milk yoghurts during storage (1-9 points)

\begin{tabular}{lcccc}
\hline \hline \multirow{2}{*}{$\begin{array}{l}\text { Characteristic - fixed date of } \\
\text { determination }\end{array}$} & \multicolumn{4}{c}{ Dose of enrichment with magnesium (mg of magnesium for 100 g of milk) } \\
\cline { 2 - 5 } & 0 & 5 & 10 & 15 \\
\hline \hline "Goat" smell - 1 day & $2.40^{\mathrm{a}} \pm 0.54$ & $1.80^{\mathrm{b}} \pm 0.44$ & $1.60^{\mathrm{b}} \pm 0.54$ & $1.40^{\mathrm{b}} \pm 0.54$ \\
"Goat" smell - 7 days & $2.40^{\mathrm{a}} \pm 0.54$ & $1.80^{\mathrm{b}} \pm 0.44$ & $1.40^{\mathrm{b}} \pm 0.54$ & $1.20^{\mathrm{c}} \pm 0.44$ \\
"Goat" smell - 14 days & $4.60^{\mathrm{a}} \pm 0.54$ & $2.60^{\mathrm{b}} \pm 1.14$ & $1.00^{\mathrm{c}} \pm 0.00$ & $1.00^{\mathrm{c}} \pm 0.00$ \\
"Goat" smell - 21 days & $5.80^{\mathrm{a}} \pm 0.14$ & $2.20^{\mathrm{b}} \pm 0.44$ & $1.00^{\mathrm{c}} \pm 0.00$ & $1.25^{\mathrm{c}} \pm 0.50$ \\
\hline
\end{tabular}

The texture, besides taste and smell, belongs to the most important characteristics of quality of fermented milk beverages. Goat's milk yoghurts are particularly exposed to occurrence of defects in texture since the acidic curd from goat's milk is characterized by lower conciseness than the curd from cow's milk (Wszolek 1997). The basic parameter of texture noted in tests was hardness of curd and the influence of dose of fortification with magnesium on the obtained result (Tab 10). In yoghurts enriched with $20 \mathrm{mg}$ of magnesium there was obtained almost two times higher hardness of curd for the whole period of the experiment in comparison to yoghurts without enrichment. Within the period from seven days until the end of period of cold storage there were found highly significant 
$(\mathrm{p}<0.01)$ differences in hardness of curds in yoghurts of all analysed groups enriched with magnesium, which is interesting information for producers. Selection of an appropriate dose of chloride and putting in specified doses of magnesium can create and correct hardness of curd in yoghurts produced from goat's milk. Other characteristics which turned out to be significant for assessment of texture metric profile of curds depending on the degree of enrichment with magnesium were resilience and gumminess of yoghurts (Tab 11 and 12). It should be stated that the level of these characteristics was significantly influenced by fortification with magnesium since there were found statistically significant differences $(\mathrm{p}<0.01)$ between enriched samples and test samples without addition of chloride. However, there was not observed a significant difference in gumminess and resilience between yoghurts with different degrees of enrichment, i.e. 5, 10, 15, $20 \mathrm{mg}$ of magnesium for $100 \mathrm{~g}$ of processed milk.

Table 10 The influence of dose of enrichment with magnesium on hardness of curds in goat's milk yoghurts during storage (N)

\begin{tabular}{|c|c|c|c|c|c|}
\hline \multirow{2}{*}{$\begin{array}{l}\text { Characteristic - fixed date of } \\
\text { determination }\end{array}$} & \multicolumn{5}{|c|}{ Dose of enrichment with magnesium (mg of magnesium for $100 \mathrm{~g}$ of milk) } \\
\hline & 0 & 5 & 10 & 15 & 20 \\
\hline Hardness - 1 day & $0.73^{\mathrm{a}} \pm 0.02$ & $1.01^{\mathrm{b}} \pm 0.01$ & $1.11^{\mathrm{c}} \pm 0.03$ & $1.11^{\mathrm{c}} \pm 0.05$ & $1.36^{\mathrm{d}} \pm 0.02$ \\
\hline Hardness -7 days & $0.67^{a} \pm 0.02$ & $0.99^{b} \pm 0.04$ & $1.08^{\mathrm{b}} \pm 0.03$ & $1.17^{\mathrm{d}} \pm 0.04$ & $1.34^{\mathrm{e}} \pm 0.02$ \\
\hline Hardness -14 days & $0.63^{\mathrm{a}} \pm 0.02$ & $0.93^{\mathrm{b}} \pm 0.03$ & $1.08^{\mathrm{c}} \pm 0.03$ & $1.17^{\mathrm{d}} \pm 0.04$ & $1.25^{\mathrm{e}} \pm 0.05$ \\
\hline Hardness - 21 days & $0.68^{\mathrm{a}} \pm 0.01$ & $0.89^{b} \pm 0.10$ & $1.14^{\mathrm{c}} \pm 0.02$ & $1.19^{\mathrm{d}} \pm 0.02$ & $1.31^{\mathrm{e}} \pm 0.09$ \\
\hline
\end{tabular}

Table 11 The influence of dose of enrichment with magnesium on resilience of curds in goat's milk yoghurts during storage (mm)

\begin{tabular}{lllll}
\hline \hline \multirow{2}{*}{$\begin{array}{l}\text { Characteristic - fixed date of } \\
\text { determination }\end{array}$} & \multicolumn{5}{c}{ Dose of enrichment with magnesium (mg of magnesium for 100 g of milk) } \\
\cline { 2 - 5 } & 0 & 5 & 10 & 15 \\
\hline \hline Resilience -1 day & $13.52^{\mathrm{a}} \pm 0.27$ & $14.26^{\mathrm{b}} \pm 0.22$ & $14.94^{\mathrm{b}} \pm 0.73$ & $14.83^{\mathrm{b}} \pm 1.03$ \\
Resilience -7 days & $13.80^{\mathrm{a}} \pm 0.26$ & $14.72^{\mathrm{b}} \pm 0.22$ & $14.36^{\mathrm{ab}} \pm 0.21$ & $14.45^{\mathrm{b}} \pm 0.24$ \\
Resilience -14 days & $12.95^{\mathrm{a}} \pm 0.66$ & $13.92^{\mathrm{b}} \pm 0.49$ & $14.46^{\mathrm{b}} \pm 0.57$ & $14.25^{\mathrm{b}} \pm 0.66$ \\
Resilience -21 days & $14.34^{\mathrm{a}} \pm 0.75$ & $14.51^{\mathrm{a}} \pm 0.25$ & $14.34^{\mathrm{a}} \pm 0.16$ & $14.46^{\mathrm{b}} \pm 0.23$ \\
\hline
\end{tabular}

Legend: ${ }^{a-c}-$ statistically significant differences $(\mathrm{p}<0.05)$ analysed in row

Table 12 The influence of dose of enrichment with magnesium on gumminess of curds in goat's milk yoghurts during storage (N)

\begin{tabular}{|c|c|c|c|c|c|}
\hline \multirow{2}{*}{$\begin{array}{l}\text { Characteristic - fixed date of } \\
\text { determination }\end{array}$} & \multicolumn{5}{|c|}{ Dose of enrichment with magnesium ( $\mathrm{mg}$ of magnesium for $100 \mathrm{~g}$ of milk) } \\
\hline & 0 & 5 & 10 & 15 & 20 \\
\hline Gumminess - 1 day & $0.42^{\mathrm{a}} \pm 0.02$ & $0.53^{\mathrm{b}} \pm 0.03$ & $0.58^{\mathrm{b}} \pm 0.06$ & $0.56^{\mathrm{b}} \pm 0.12$ & $0.67^{\mathrm{c}} \pm 0.00$ \\
\hline Gumminess -7 days & $0.43^{\mathrm{a}} \pm 0.01$ & $0.54^{\mathrm{b}} \pm 0.03$ & $0.57^{\mathrm{b}} \pm 0.01$ & $0.59^{\mathrm{b}} \pm 0.02$ & $0.65^{\mathrm{c}} \pm 0.01$ \\
\hline Gumminess - 14 days & $0.38^{\mathrm{a}} \pm 0.02$ & $0.48^{\mathrm{b}} \pm 0.03$ & $0.57^{\mathrm{c}} \pm 0.08$ & $0.57^{\mathrm{c}} \pm 0.05$ & $0.60^{\mathrm{c}} \pm 0.01$ \\
\hline Gumminess -21 days & $0.39^{\mathrm{a}} \pm 0.01$ & $0.52^{\mathrm{b}} \pm 0.01$ & $0.57^{b} \pm 0.02$ & $0.60^{\mathrm{b}} \pm 0.00$ & $0.63^{\mathrm{c}} \pm 0.04$ \\
\hline
\end{tabular}

Legend: ${ }^{a-c}-$ statistically significant differences $(p<0.05)$ analysed in row

\section{CONCLUSION}

Goat's milk can be enriched with magnesium in the form of chloride before pasteurization with a safe dose, i.e. $20 \mathrm{mg}$ of magnesium for $100 \mathrm{~g}$ of milk Higher doses of magnesium can lead to coagulation of proteins since together with the increase of dose of fortification with magnesium chloride there increases general acidity, and $\mathrm{pH}$ of milk decreases. The doses higher than $21 \mathrm{mg}$ of magnesium for $100 \mathrm{~g}$ of goat's milk can cause denaturation of proteins during pasteurization

Together with the increase of dose of fortification with magnesium there was found a significant proportional increase in acidity and hardness of curds persisting for 21 days of storage of yoghurts. Enrichment of goat's milk yoghurts with magnesium lowered the intensity of ,goat” smell and aftertaste.

\section{REFERENCES}

MITUNIEWICZ-MAŁEK, A., DMYTRÓW, I., NOWAK, Z. 2009. Qualitative characteristics of cold stored yoghurt produced from goat's milk. Przegląd Mleczarski, 7, 4-8.

NAVARRO-ALARCÓN, M., CABRERA-VIQUE, C., RUIZ-LÓPEZ, M. D. OLALLA, M., ARTACHO, R., GIMÉNEZ, R., QUINTANA, V., BERGILLOS, T. 2011. Levels of $\mathrm{Se}, \mathrm{Zn}, \mathrm{Mg}$ and $\mathrm{Ca}$ in commercial goat and cow milk fermented products: Relationship with their chemical composition and probiotic starter culture. Food Chemistry, 129, 1126-1131. http://dx.doi.org/10.1016/j.foodchem.2011.05.090

PAZÁKOVÁ, J., BURDOVÁ, O., TUREK, P., LACIAKOVÁ, A. 1999. Sensorial evaluation of yoghurt produced from cow, sheep's and goat's milk. Czech Journal of Food Sciences, 17, 31-34.

RIBEIROA, A.C., RIBEIROA, S.D.A. 2010. Specialty products made from goat milk. Small Ruminant Research, 89, 225-233. http://dx.doi.org/10.1016/j.smallrumres.2009.12.048

TAMIME, A. Y., KALAB, M., DAVIES, G. 1984. Microstructure of set- style yoghurt manufactured from cow's milk fortified by various methods. Food Microstructure, 3, 83-92.

TAMIME, A. Y., MUIR, D.D. 1998. Strategies for modifying the structure of fermented milks. Texture of fermented milk products and dairy desserts. IDF Special Issue, 9802, 186-196.

WOJTASZEK, T. 2004. Functional beverages. Fermentation and fruit-vegetable industry, 5, 42-43.

WSZOŁEK, M. 1997. Technological usefulness of goat's milk. Przeglad Mleczarski, 1, 12-14.
ZIARNO, M. 2004. Dairy products enriched with magnesium. Przemyst Spożywczy, 12, 38-41.

ZIARNO, M. 2008. Enriching milk with calcium salts and magnesium salts. Przegląd Mleczarski, 2, 4-10.

ZIARNO, M., ZAREBA, D., PISKORZ, J. 2009. Enriching buttermilk with calcium, magnesium and whey proteins. Żywność. Nauka. Technologia. Jakość, 2(63), 14-27. 